\title{
Modulation of the IgH enhancer's cell type specificity through a genetic switch
}

\author{
Diane Ruezinsky, ${ }^{1,2}$, Holger Beckmann, ${ }^{1}$ and Tom Kadesch \\ Howard Hughes Medical Institute and the Department of Human Genetics, University of Pennsylvania School of Medicine, \\ Philadelphia, Pennsylvania 19104-6148 USA
}

\begin{abstract}
Using defined regions of the immunoglobulin heavy-chain enhancer linked to minimal promoters and cDNAs that encode the two helix-loop-helix transcription factors ITF-1 and TFE3, we demonstrate that activity of an otherwise repressed enhancer can be stimulated in nonlymphoid cells. Repression in non-B cells is mediated by the $\mu E 5$ motif. Derepression occurs at two levels. First, overexpression of ITF-1, an E12/E47-related protein that binds the $\mu E 5$ motif, leads to transcriptional activation itself. Second, binding of ITF-1 physically displaces a repressor that normally blocks the stimulatory activity of TFE3, which binds the neighboring $\mu E 3$ motif. TFE3 can only stimulate enhancer activity in the presence of ITF-1 or in the absence of a $\mu E 5$ motif. Hence, one component of the enhancer's cell type specificity can be artificially modulated through a "genetic switch" in which activity is dictated by the relative levels of ITF-1 and a competing repressor.
\end{abstract}

[Key Words: Helix-loop-helix proteins; transcriptional activation; transcriptional repression; immunoglobulin enhancer; transcription factors ITF-1 and TFE3]

Received September 21, 1990; revised version accepted November 14, 1990.

Activity of the immunoglobulin heavy chain $(\operatorname{IgH})$ enhancer is limited to cells of the lymphoid lineage, primarily B cells. The approximate 250 bp that make up the enhancer have been shown to bind at least eight distinct proteins (for review, see Atchison 1988). The binding motifs are referred to as $\mathrm{E}, \mu \mathrm{E} 1, \mu \mathrm{E} 5$ (equivalent to $\kappa \mathrm{E} 2$ ), $\mu \mathrm{E} 2, \mu \mathrm{E} 3, \mu \mathrm{B}, \mu \mathrm{E} 4$, and octamer (the latter refers to the conserved octanucleotide ATTTGCAT), and mutations introduced into these sites generally reduce enhancer activity (Lenardo et al. 1987; Kiledjian et al. 1988; PerezMetul et al. 1988; Tsao et al. 1988; Libermann et al. 1990; Nelsen et al. 1990). The mechanisms that govern the B-cell specificity of the enhancer are not fully understood, although evidence to date suggests that it is determined by both positive and negative control. Support for positive control stems from the identification of Bcell-specific proteins that bind to the octamer motif (Oct-2; Ko et al. 1988; Muller et al. 1988; Scheidereit et al. 1988) and to a site adjacent to $\mu \mathrm{E} 3$ (NF- $\mu \mathrm{B}$; Araki et al. 1988; Libermann et al. 1990; Nelsen et al. 1990). Other proteins shown to bind the enhancer in vitro appear to be present in many cell types. Evidence for negative control comes from the identification of deletions that result in significant, albeit low, levels of enhancer activity in nonlymphoid cells (Kadesch et al. 1986; Wasylyk and Wasylyk 1986; Imler et al. 1987; Weinberger et al. 1988). Negative regulation is also indicated by experiments with $\mathrm{B} \times \mathrm{T}$ hybrid cells within which $\mathrm{IgH}$ en-

\footnotetext{
${ }^{1}$ This work resulted from an equal contribution by the first two authors. ${ }^{2}$ Present address: Plant Biology Laboratory, Salk Institute for Biological Studies, La Jolla, California 92037 USA.
}

hancer activity is actively extinguished (Yu et al. 1989). Taken together, the evidence suggests that multiple, independent mechanisms may confer both positive and negative regulation.

A specific need for negative control might be inferred by the recent analyses of immunoglobulin transcription factor cDNAs. Two distinct genes encode proteins that bind both the $\mu \mathrm{E} 5$ and $\kappa \mathrm{E} 2$ motifs (Murre et al. 1989a; Henthorn et al. 1990a), and at least two additional genes encode distinct $\mu$ E3-binding (Beckmann et al. 1990) and E-binding (Roman et al. 1990) proteins. For the case of the $\mu E 5 / \kappa E 2-b i n d i n g$ proteins, three forms (ITF-1, E12, and E47) arise from a single gene through alternate splicing or promoter utilization. At least one of these, denoted ITF-1 (identical to E47 except for its first coding exon; Henthorn et al. 1990b; Kamps et al. 1990; Nourse et al. 1990|, functions as a positive-acting transcription factor in transfection experiments of both mammalian cells and yeast (Henthorn et al. 1990a). The $\mu$ E3-binding protein, TFE3, also functions as a positive-acting transcription factor. Interestingly, an E-binding protein, denoted $\mathrm{Ig} / \mathrm{EBP} 1$, has been shown to form heterodimers with the transcription factor C/EBP /CAAT enhancerbinding protein). All of the genes that encode these particular enhancer-binding proteins are transcribed in both $\mathrm{B}$ and non-B cells. Hence, a negative regulatory mechanism would ensure that the action of these apparently ubiquitous positive-acting factors be limited to B cells.

We show here that the one component of the $\operatorname{IgH}$ enhancer's overall B-cell specificity is indeed due to negative control. The site that mediates this control is capable of repressing the otherwise ubiquitous activity of a 
nearby site. Derepression and, consequently, enhancer activation in non-B cells can be achieved by overexpressing the positive-acting transcription factor, ITF-1, which apparently competes with a repressor for overlapping DNA sites.

\section{Results \\ The $\mu E 5$ motif represses activity of the $\mu E 3$ motif in nonlymphoid cells}

Previous experiments have shown that enhancer deletions that remove nucleotides near the $\mu \mathrm{E} 2$ motif can result in low-level enhancer activity in non-B cells $/ \mathrm{Ka}-$ desch et al. 1986; Wasylyk and Wasylyk 1986; Weinberger et al. 1988). To assess more simply the relative contributions of individual protein-binding motifs within this region, we adopted the approach of examining the behavior of small oligonucleotides (oligos) that carry only one or two known motifs, either individually or in combination. We have studied the behavior of two such oligos that carry either the $\mu \mathrm{E} 3$ motif alone or the $\mu \mathrm{E} 5$ and $\mu \mathrm{E} 2$ motifs together (Fig. 1). The two oligos were designed to carry either normal or mutant motifs and, when linked together, to preserve the normal motif spacing found in the enhancer.

Each oligo, either singly or as multiple tandem copies, was placed upstream of a minimal LBK alkaline phosphatase promoter containing only a TATA box (Kiledjian and Kadesch 1990) linked to the bacterial cat gene (expressing chloramphenicol acetyltransferase, CATase; Gorman et al. 1982). The resulting plasmids were then transfected into either B cells (P3-X63Ag8) or non-B cells (NIH-3T3), and CATase activity was determined. As shown in Figure 2 (top, row A), a single $\mu \mathrm{E} 3$ oligo was not capable of activating transcription from the TATAbox promoter. However, four tandem copies of the $\mu \mathrm{E} 3$ oligo did activate transcription and, when compared to reporter plasmids containing the SV40 enhancer/data not shown), did so with roughly equal efficiency in both $B$ cells and non-B cells (row C). This activity was due specifically to the $\mu \mathrm{E} 3$ motif because activity was not seen with four tandem copies of an oligo carrying a mutant $\mu \mathrm{E} 3$ motif (row D). The oligo carrying both the $\mu \mathrm{E} 5$ and $\mu \mathrm{E} 2$ motifs $(\mu \mathrm{E} 5+\mu \mathrm{E} 2)$, even when polymerized to six tandem copies, was unable to activate transcription efficiently from the minimal promoter in either $B$ or non-B cells (row E). However, when polymerized to 12 tandem copies, low levels of activation were obtained in B cells (data not shown). We conclude from these experiments that the $\mu \mathrm{E} 3$ motif is capable of binding transcription factors from both B cells and non-B cells, whereas the $\mu E 5+\mu E 2$ oligonucleotide, although capable of binding factors, can stimulate transcription only weakly in B cells.

A very different pattern of expression was observed when the two oligos were first linked together and then polymerized to four tandem copies (Fig. 2). First, although we were unable to detect activity of four copies of the $\mu \mathrm{E} 5+\mu \mathrm{E} 2$ oligo on its own, when linked to the $\mu \mathrm{E} 3$ oligo and polymerized to four tandem copies it stimulated activity (on average twofold) in B cells and drastically suppressed activity in non-B cells (row G). By employing a series of mutant $\mu \mathrm{E} 5+\mu \mathrm{E} 2$ oligos (see Fig. 1), we established that its stimulatory effect in lymphoid cells was due both to the $\mu \mathrm{E} 5$ and $\mu \mathrm{E} 2$ motifs (rows $\mathrm{H}-\mathrm{J}$ ). However, the suppression of non-B-cell activity was due primarily to the $\mu \mathrm{E} 5$ motif because mutations in the $\mu \mathrm{E} 5$ motif uniquely restored activity of the $\mu \mathrm{E} 3$ oligo in non-B cells (rows $\mathrm{H}$ and J). The threefold difference in CATase levels observed with duplicate transfections of plasmid $\mathrm{C}$ into NIH-3T3 cells (Fig. 2) is not representative of the normal experimental variation in this experiment or in those that follow. Relative values obtained from any given transfection were generally found to be reproducible (see Materials and methods).

Our data demonstrate that the IgH enhancer's B-cellrestricted activity can be recapitulated with simply the $\mu \mathrm{E} 5$ and $\mu \mathrm{E} 3$ protein-binding motifs. The results are consistent with a model in which the $\mu \mathrm{E} 3$ motif binds a ubiquitous transcription factor. However, in non-B cells, its activity is repressed by the $\mu E 5$ motif, which presumably binds a repressor protein. In B cells the repression is absent and both the $\mu \mathrm{E} 5$ and $\mu \mathrm{E} 3$ motifs stimulate transcription.

Derepression of cell type specificity through the action of a positive-acting transcription factor

Rationale The $\mu \mathrm{E} 5$ and $\mu \mathrm{E} 3$ motifs are known to bind positive-acting transcription factors. Recently, several
Figure 1. Nucleotide sequence of the $\mu E 5, \mu E 2$, and $\mu E 3$ region of the $\operatorname{IgH}$ enhancer and of oligonucleotides incorporated into minimal promoters. Sequence of the enhancer from nucleotides 364 to 425 is shown above the $\mu \mathrm{E} 5+\mu \mathrm{E} 2$ and $\mu \mathrm{E} 3$ oligonucleotides. Sequences of oligonucleotides with mutant motifs (mut) are shown. The normal (i.e., nonmutant) $\mu \mathrm{E} 5, \mu \mathrm{E} 2$, and $\mu \mathrm{E} 3$ motifs are indicated schematically by $\boldsymbol{\Delta}, \boldsymbol{\theta}$, and $\boldsymbol{\square}$, respectively.

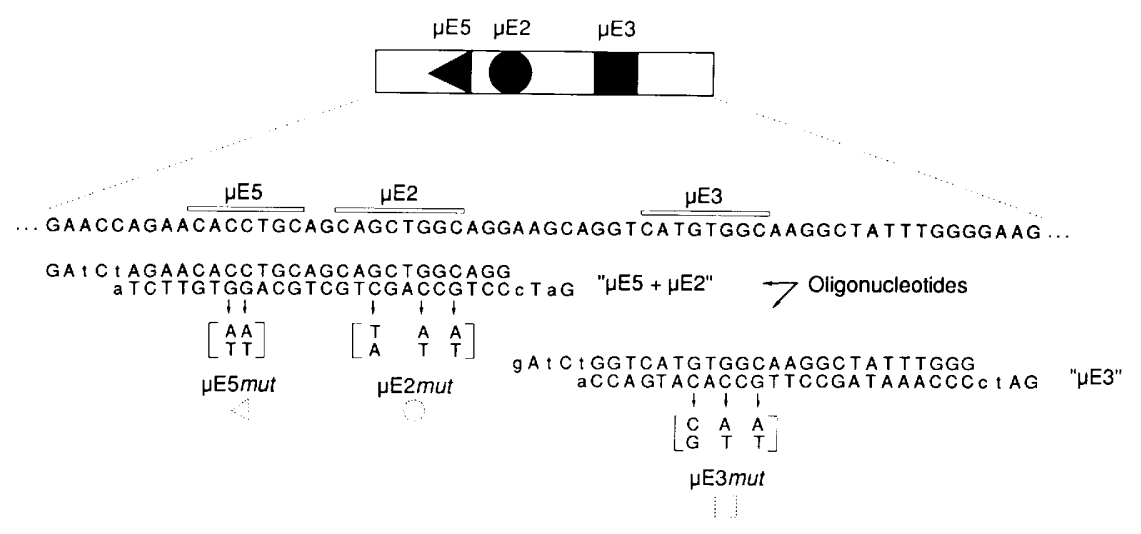



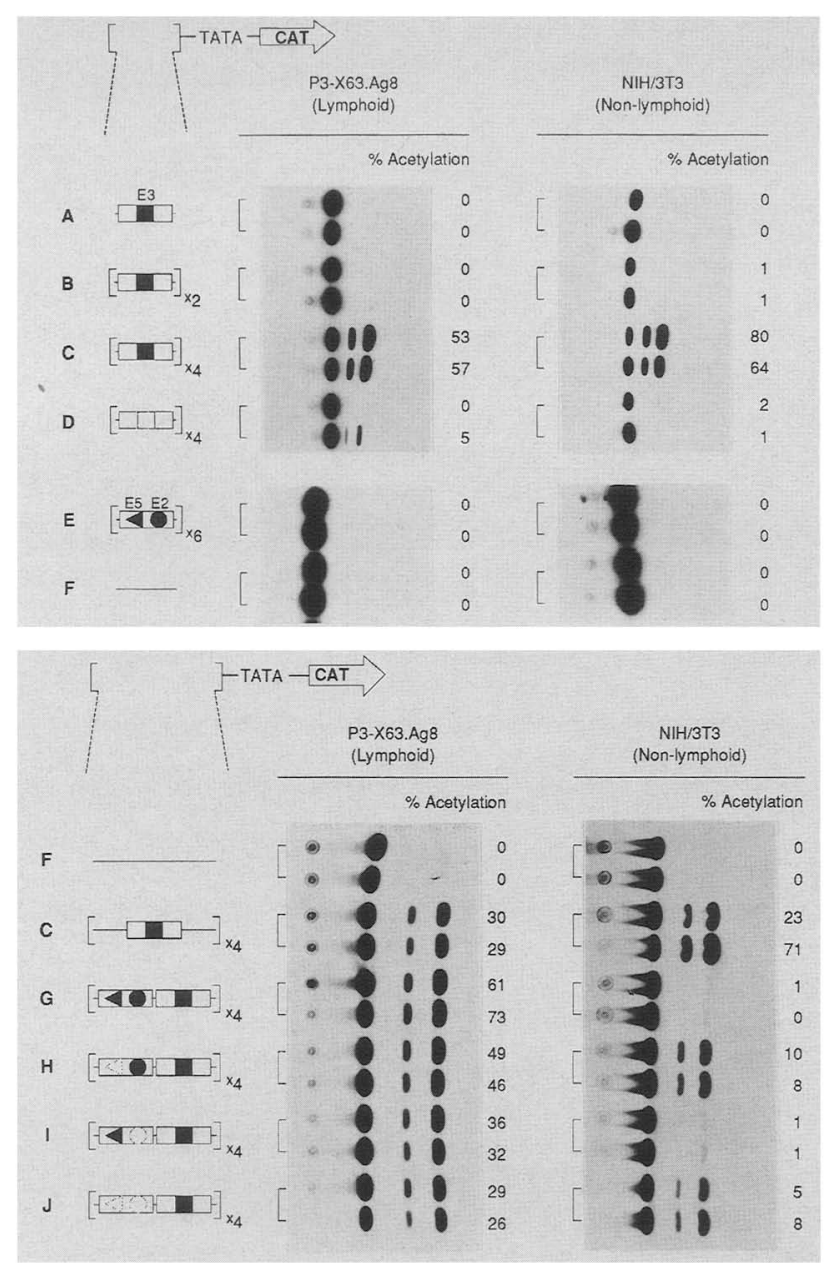

Figure 2. Lymphoid-restricted transcriptional activity is reconstituted by the $\mu \mathrm{E} 5$ and $\mu \mathrm{E} 3$ motifs of the $\operatorname{IgH}$ enhancer. P3-X63Ag.8 and NIH-3T3 cells were transfected with TATAcat reporter plasmids carrying the indicated numbers of oligonucleotides (see Fig. 1) as described (NIH-3T3 cells were transfected with $10 \mu \mathrm{g}$ of each reporter plasmid). Autoradiograms show duplicate transfections for each plasmid and normalized (i.e., relative) CATase activities expressed as percent acetylation. (Top) Transcriptional activities of individual oligonucleotides. Row $D$ depicts results obtained with four tandem copies of a mutant $\mu \mathrm{E} 3$ motif. Row $F$ shows the results obtained with no oligonucleotide. (Bottom) Effects of linking normal or mutant $\mu \mathrm{E} 5+\mu \mathrm{E} 2$ oligonucleotides to the $\mu \mathrm{E} 3$ oligonucleotide.

cDNAs have been isolated that encode $\mu \mathrm{E} 5$ - (and $\mathrm{kE} 2$ )binding proteins (E12, E47, ITF-1, and ITF-2; Murre et al. 1989a, Henthorn et al. 1990al and at least one cDNA that encodes a $\mu$ E3-binding protein (TFE3; Beckmann et al. 1990). Although all of these cDNAs were isolated from B-cell-derived libraries, all of the corresponding mRNAs are detectable in multiple cell types. All are helix-loop-helix proteins. At least one of the $\mu E 5$ binding proteins, ITF-1, and the $\mu \mathrm{E} 3$-binding protein, TFE3, are positive-acting transcription factors (Beckmann et al. 1990; Henthorn et al. 1990a). Therefore, it was not surprising to us that the $\mu \mathrm{E} 3$ oligonucleotide stimulated transcription in both $\mathrm{B}$ and non-B cells. However, the presence of ITF-1 (E12/E47) RNA in non-B cells suggested at least two explanations for why the $\mu \mathrm{E} 5$ motif did not stimulate transcription in non-B cells. First, functional ITF-1 protein may not be produced in non-B cells due to either a translational block or a posttranslational modification. Second, ITF-1 protein may be present, but its binding to the $\mu \mathrm{E} 5$ motif may be precluded by the presence of the repressor protein whose existence we have postulated here. In this latter case, repression or activation may be established by the relative ratios of the repressor and ITF-1.

To examine further the nature of $\mu \mathrm{E} 5$-mediated repression in non-B cells, we transfected NIH-3T3 cells with various reporter plasmids along with additional plasmids that express either TFE3 or ITF-1 (Beckmann et al. 1990; Henthorn et al. 1990a). It was reasoned that these experiments would allow us to examine the effects of elevated levels of TFE3 and/or ITF-1 on the repression phenotype.

The first set of three reporter plasmids and the accompanying results of transfecting NIH-3T3 cells are shown in Figure 3. Two of the reporters are equivalent to those described in Figure 2 (rows $\mathrm{G}$ and H) and carry either a normal or mutant $\mu \mathrm{E} 5$ motif (with the accompanying $\mu \mathrm{E} 2$ motif intact) linked to the $\mu \mathrm{E} 3$ motif. The third reporter carries a $\kappa \mathrm{E} 2$ motif linked to the $\mu \mathrm{E} 3$ motif. The кE2 motif shares seven contiguous base pairs with the $\mu \mathrm{E} 5$ motif, and both motifs are known to bind the ITF-1, $\mathrm{E} 12$, and $\mathrm{E} 47$ proteins (the $\mathrm{kE} 2$ and $\mu \mathrm{E} 5$ motifs are present in opposite orientations). The first lane with each reporter represents results of transfections using 10 $\mu \mathrm{g}$ of reporter plasmid DNA alone (lanes 1, 6, and 11). These data confirm the results shown in Figure 2 and further illustrate that the $\kappa E 2$ motif also represses $\mu E 3$-mediated activity in non-B cells. The remainder of the lanes for each reporter represent experiments in which only $l \mu \mathrm{g}$ of reporter plasmid DNA was transfected. When $1 \mu \mathrm{g}$ of any of the reporter plasmids was transfected alone, CATase activity for each case fell below our level of detection (lanes 2, 7, and 12).

When the TFE3 expression plasmid was included in the transfections, CATase activity was obtained, but only in conjunction with the reporter carrying the mutated $\mu$ E5 element (lanes 3, 8, and 13). Hence, both the $\mu \mathrm{E} 5$ and $\mathrm{kE} 2$ motifs are individually capable of repressing $\mu \mathrm{E} 3$-mediated activity, even in the presence of elevated levels of TFE 3 protein.

A very different result was obtained when a plasmid expressing ITF-1 was included in the transfections (Fig. 3 , lanes 4,9 , and 14). Transcriptional activation was obtained primarily through the $\mu \mathrm{E} 5$ motif (poor activation was obtained with the reporter carrying a mutant $\mu \mathrm{E} 5$ site), and to a lesser extent, the $\mu \mathrm{E} 2$ site (activation was abolished with a $\mu \mathrm{E} 5, \mu \mathrm{E} 2$ double mutant; data not shown). Activation was also mediated through the $\mathrm{kE} 2$ motif. Hence, in the presence of elevated levels of ITF-1, the $\mu E 5, \mu E 2$, and $k E 2$ motifs support transcriptional activation in non-B cells. Activation by ITF-1 alone did not depend on, nor was it influenced by, the presence of the $\mu E 3$ site (M. Kiledjian and T. Kadesch, unpubl.).

When both plasmids expressing the ITF- 1 and TFE 3 were included in the transfections (Fig. 3, lanes 5, 10, 


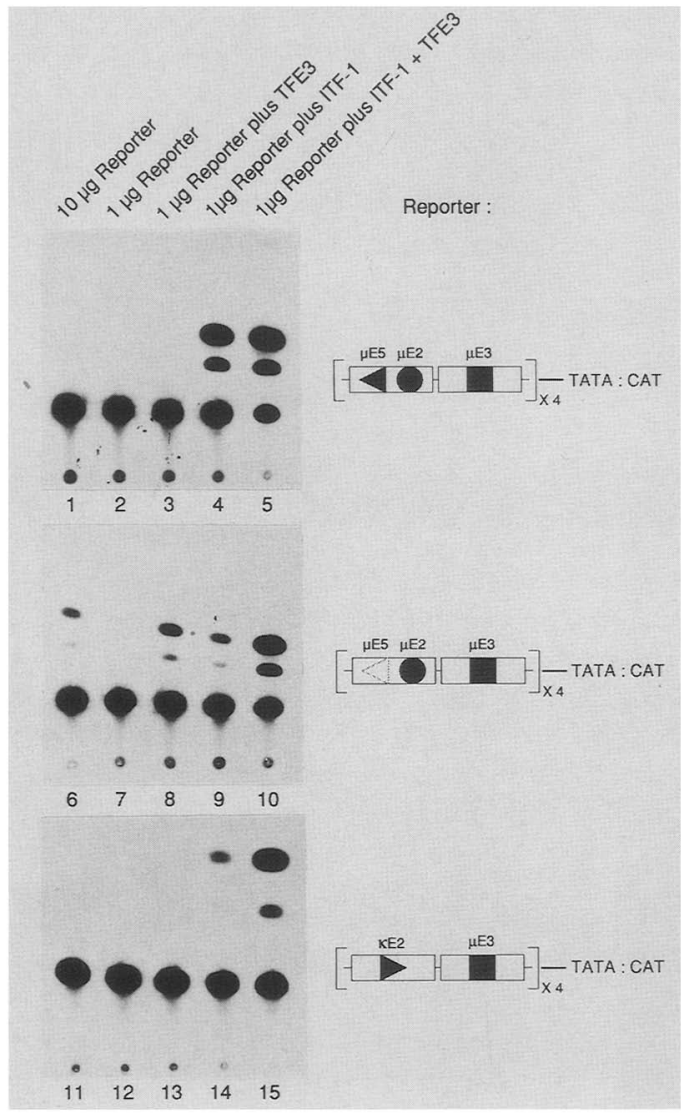

Figure 3. Elevated levels of ITF-1 activate transcription from repressed minimal promoters. NIH-3T3 cells were transfected with the indicated plasmids and assayed for CATase as described using either $10 \mu \mathrm{g}$ (lanes 1, 6,11) or $1 \mu \mathrm{g}$ of the indicated reporter plasmids (the oligonucleotide carrying the $\kappa E 2$ motif is described in Materials and methods). In addition, cells were transfected with $10 \mu \mathrm{g}$ of pSV2A 3 (which expresses TFE3; lanes 3,8 , and 13) or $5 \mu \mathrm{g}$ of pSVE2-5 (which expresses ITF-1; lanes 4,9 , and 14) or both of these plasmids (lanes 5, 10, and 15). The total mass of plasmid for each transfection (including $5 \mu \mathrm{g}$ of $\mathrm{pCHl} 10$, which expresses $\beta$-galactosidase) was adjusted to 21 $\mu \mathrm{g}$ with the addition of pUC19. The autoradiograms show representative experiments that were confirmed by at least three separate transfections. After nomalizing to $\beta$-galactosidase, CATase values were 0.25 (lane 1); 0.13 (lane 2); 0.15 (lane 3); 30 (lane 4); 58 (lane 5); 2.0 (lane 6); 0.32 (lane 7); 5.5 (lane 8); 3.4 (lane 9); 41 (lane 10); 0.80 (lane 11); 0.60 (lane 12); 0.60 (lane 13); 2.5 (lane 14); 50 (lane 15).

and 15), the levels of CATase obtained were greater than the sum expected from the ITF-1 and TFE 3 expression plasmids alone. Using the reporter with intact $\mu \mathrm{E} 5$ and $\mu E 3$ elements, a combination of TFE3 plus ITF-1 stimulated transcription approximately twofold more than ITF-1 alone. This synergistic effect was more readily apparent with the reporter carrying the linked $\kappa \mathrm{E} 2$ and $\mu \mathrm{E} 3$ motifs. Detectable stimulation of CATase activity by TFE3 was seen only in the presence of ITF-1. This result argues that the repressive effects of the $\mu \mathrm{E} 5$ motif on the $\mu \mathrm{E} 3$ site are diminished or perhaps abolished in the presence of excess ITF-1 protein.

\section{Stimulation of $\operatorname{IgH}$ enhancer activity in non-B cells}

We have shown that the IgH enhancer's B-cell specificity can be simply recapitulated with the two motifs $\mu \mathrm{E} 5$ and $\mu \mathrm{E} 3$. Although our results to this point provide compelling evidence concerning the nature of that specificity, we sought to confirm our results with larger segments of the enhancer. We reasoned that the activities of the $\mu \mathrm{E} 5$ and $\mu \mathrm{E} 3$ motifs and their responses to ITF-1 and TFE 3 should be assessed within the motifs' normal enhancer context. Therefore, we employed reporter plasmids that carry intact or mutated enhancers, present as single or multiple tandem copies, placed $3^{\prime}$ of a transcription unit consisting of the human $\beta$-globin promoter linked to the cat gene (Kiledjian et al. 1988). Hence, these reporter plasmids also allow us to measure the effects of ITF- 1 and TFE 3 on enhancer activity per se, namely, on transcriptional activation at a distance.

The first two enhancer fragments tested and the corresponding transfection results are shown in Figure 4A. Both enhancers (fragment 18, from Kiledjian et al. 1988) extend from the $X b a I$ site (position 1) to the third enhancer core element (position 474; numbering of Gillies et al. 1983) and therefore lack the $\mu \mathrm{E} 4$ and octamer motifs. Although both carry an intact $\mu \mathrm{E} 3$ motif, one carries a deletion between the $\mu \mathrm{E} 1$ and $\mu \mathrm{E} 2$ motifs and, hence, is also missing the $\mu \mathrm{E} 5$ motif. Both were tested as 12 tandem copies.

The results obtained upon transfecting these reporter plasmids into NIH-3T3 cells alone or in combination with plasmids that express TFE 3 and/or ITF- 1 confirm the results obtained with the minimal promoters /see Fig. 3). First, if the $\mu E 5$ motif is deleted, the enhancer becomes active in non-B cells (Fig. 4A, cf. lanes 1 and 6). Second, under conditions where activity of the reporters alone is not detected ( $1 \mu \mathrm{g}$ of transfected plasmid DNA as opposed to $10 \mu \mathrm{g}$; lanes 2 and 7), transfections of plasmids bearing the TFE 3 cDNA activate the enhancer only in the absence of the $\mu \mathrm{E} 5$ motif (lanes 3 and 8). Third, transfecting a plasmid that expresses the ITF-1 cDNA leads to enhancer activation and this requires the $\mu \mathrm{E} 5$ motif (and to a lesser degree the $\mu \mathrm{E} 2$ site). Fourth, activity derived from ITF-1 plus TFE3 is greater than the sum of their individual stimulatory activities. It was confirmed that in this latter context stimulation by TFE3 required an intact $\mu E 3$ site (data not shown).

We also tested the effects of TFE3 and ITF- 1 overexpression on the activity of a fully intact $\mathrm{IgH}$ enhancer (Fig. 4B). The enhancer used for these experiments (fragment 2, from Kiledjian et al. 1988) extends from a HinfI site (position 345) to an EcoRI site (position 683) and thus includes all the major motifs known to be important for enhancer activity. When linked to the $\beta$-globin cat reporter as 12 tandem copies, it could not be activated in NIH-3T3 cells by overexpressing TFE3 (lane 2), but could be activated by ITF-1 (lane 3). Again, these results are in agreement with those presented with our other reporter plasmids. With a single copy of this enhancer linked to the $\beta$-globin cat reporter, ITF-1 alone could not stimulate to a detectable level (lane 7), but ITF-1 in combination with TFE3 could. 

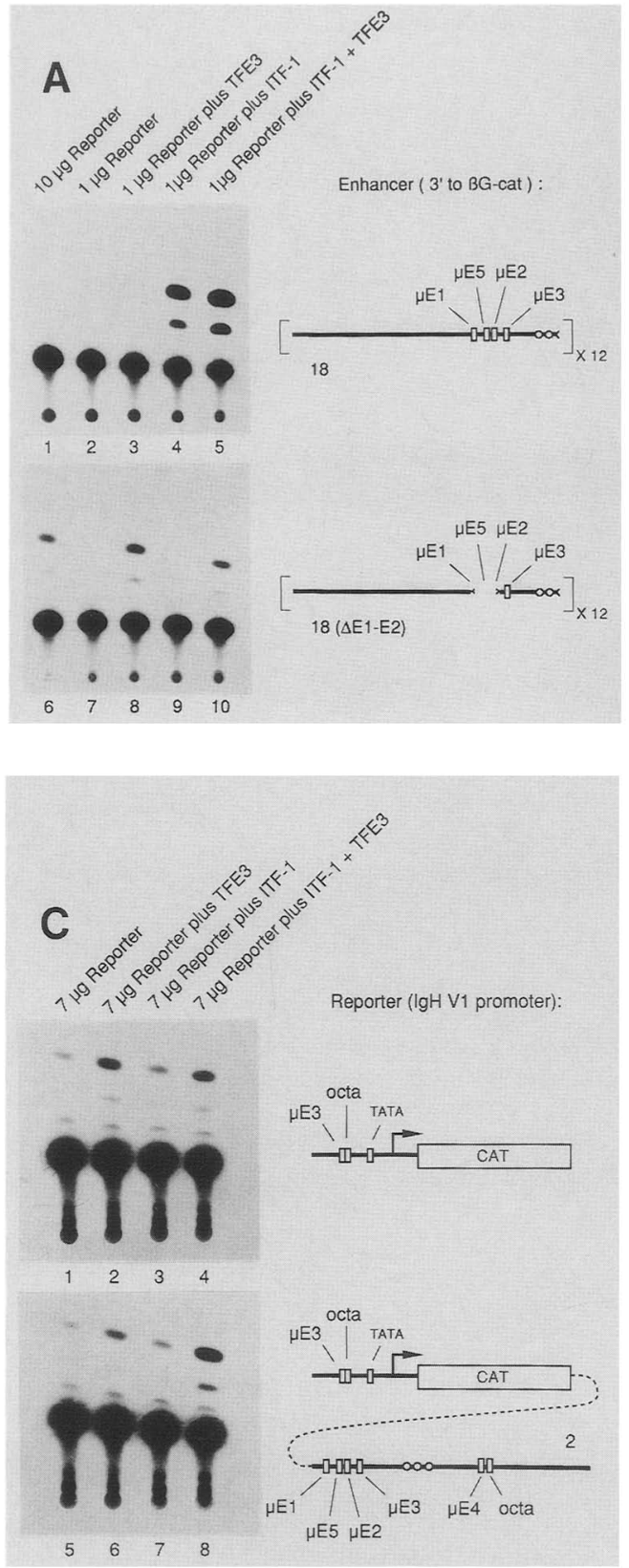

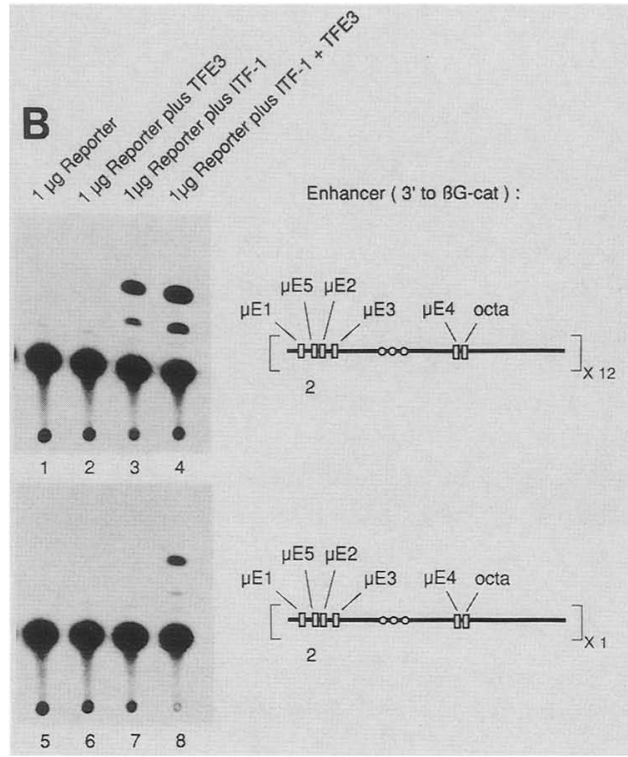

Figure 4. Elevated levels of ITF-1 derepress the $\mathrm{IgH}$ enhancer in NIH-3T3 cells. Transfections were carried out as described in the legend to Fig. 3 using the indicated amounts of reporter plasmids. Reporter plasmids carrying the indicated enhancer fragments $3^{\prime}$ to a $\beta$-globin-cat or IgH-V1-cat transcription unit are described in Materials and methods. (A) Activating effects of ITF-1 and TFE3 on enhancers with or without the $\mu E 1, \mu E 5$, and $\mu E 2$ motifs. Relative CATase levels were 0.6 (lane 1 ); 1.4 (lane 2); 0.3 (lane 3); 4.1 (lane 4); 4.8 (lane 5); 2.4 (lane 6); 0.2 (lane 7); 3.3 (lane 8); 0.4 (lane 9); 1.7 (lane 10). (B) Activating effects of ITF- 1 and TFE 3 on intact enhancers carried as 12 tandem copies or as 1 copy. Relative CATase levels were 0.04 (lane 1); 0.10 (lane 2); 2.3 (lane 3); 5.6 (lane 4); 0.05 (lane 5); 0.08 (lane 6); 0.09 (lane 7); 0.55 (lane 8). (C) Activating effects of ITF- 1 and TFE 3 on a V1 promoter or a V1 promoter linked to one copy of the intact enhancer $(3.5 \mu \mathrm{g}$ of pCH1 10 was used to normalize transfection efficiencies). Relative CATase levels were 0.22 (lane 1 ); 0.42 (lane 2); 0.22 (lane 3); 0.41 (lane 4); 0.13 (lane 5); 0.40 (lane 6); 0.17 (lane 7); 1.0 (lane 8).

promoter (Fig. 4C). The V1 IgH promoter has been reported to contain a $\mu$ E3 site (Peterson and Calame 1989), and consistent with this we found that it alone was weakly stimulated by TFE3 in NIH-3T3 cells /cf. lanes 1 and 2). ITF-1 was unable to stimulate the promoter alone. However, when the promoter was linked to the IgH enhancer, a combination of ITF-1 and TFE3 was found to stimulate the promoter very well (lane 8 ). Neither TFE3 nor ITF-1 could effect the stimulation as well (lanes 6 and 7). As expected, both the $\mu \mathrm{E} 3$ and $\mu \mathrm{E} 5$ sites were required for the activation (data not shown). These results corroborate our previous findings and demonstrate that ITF-1 and TFE3 function synergistically to activate the enhancer and immunoglobulin gene transcription. 


\section{Discussion}

\section{Activation of the IgH enhancer in non-B cells}

The results presented here demonstrate that B-cell specificity of the $\mathrm{IgH}$ enhancer can be recapitulated by the two protein-binding motifs, $\mu \mathrm{E} 5$ and $\mu \mathrm{E} 3$. In B cells, both motifs act to stimulate transcription. This is consistent with the recent isolation, from B-cell-derived libraries, of cDNAs that encode $\mu \mathrm{E} 5$ - and $\mu \mathrm{E} 3$-binding proteins that function as positive-acting transcription factors (Beckmann et al. 1990; Henthorn et al. 1990a). In non-B cells an isolated $\mu \mathrm{E} 3$ motif stimulates transcription, but if it is linked to either a $\mu E 5$ or $\kappa E 2$ motif, transcription stimulation is abolished. The repressive activities of the $\mu E 5$ and $\kappa E 2$ motifs are maintained even under conditions where transfected cells express highly elevated levels of the $\mu \mathrm{E} 3$-binding transcription factor TFE3. In fact, our estimates suggest that the $\mu E 5$ motif is capable of repressing TFE3-mediated activity by $>50$ fold. Although we have no direct in vitro physical evidence for a repressor protein binding to the $\mu \mathrm{E} 5$ motif, our in vivo functional data support the existence of such a protein (or protein complex).

The repressive activities of the $\mu \mathrm{E} 5$ and $\mathrm{\kappa E} 2$ motifs are not seen in the presence of elevated levels of the $\mu \mathrm{E} 5$ binding transcription factor ITF-1. One interpretation is diagramed in Figure 5 and proposes that ITF- 1 binding physically displaces the repressor. Two arguments support this model. First, the repressor site and the ITF-1binding site overlap. Mutations of $2 \mathrm{bp}$ within the $\mu \mathrm{E} 5$ motif (see Fig. 1) that reduce the binding of ITF-1 also fail to repress. Moreover, the $\mathrm{kE} 2$ motif, which is identical to the $\mu \mathrm{E} 5$ motif in seven out of seven contiguous base pairs, also both represses the $\mu \mathrm{E} 3$ motif and binds ITF-1. Hence, the repressor element and the ITF-1binding site are probably both found within that 7-bp identity. Second, enhancer activation by TFE 3 is seen only in the absence of a $\mu \mathrm{E} 5$ motif or in the presence of elevated levels of ITF-1. One prediction of the model is that mutant forms of ITF-1 that can bind DNA, but cannot activate transcription themselves, should allow activation by TFE3. Our attempts to express these types of mutant ITF-1 proteins in cells have not yet been successful.

Synergistic activation of the enhancer by ITF-1 and TFE3 was observed in several of our experiments. This was manifested in two ways. First, with the exception of the Vl promoter, we have not observed transcriptional stimulation by TFE3 alone of minimal promoters carrying single $\mu \mathrm{E} 3$ sites or of single copies of the enhancer. Since TFE 3 readily activates promoters carrying multiple $\mu \mathrm{E} 3$ motifs and activates multiple copies of the enhancer (lacking the $\mu$ E5 site), we conclude that TFE3 is able to function synergistically with itself. The same conclusions hold true for activation by ITF-1 alone. Second, the levels of stimulation by ITF-1 plus TFE3 were always higher than the sum of those obtained with either transcription factor alone. Hence, TFE3 is able to function synergistically with ITF-1. The magnitude of these latter effects varied between individual reporter

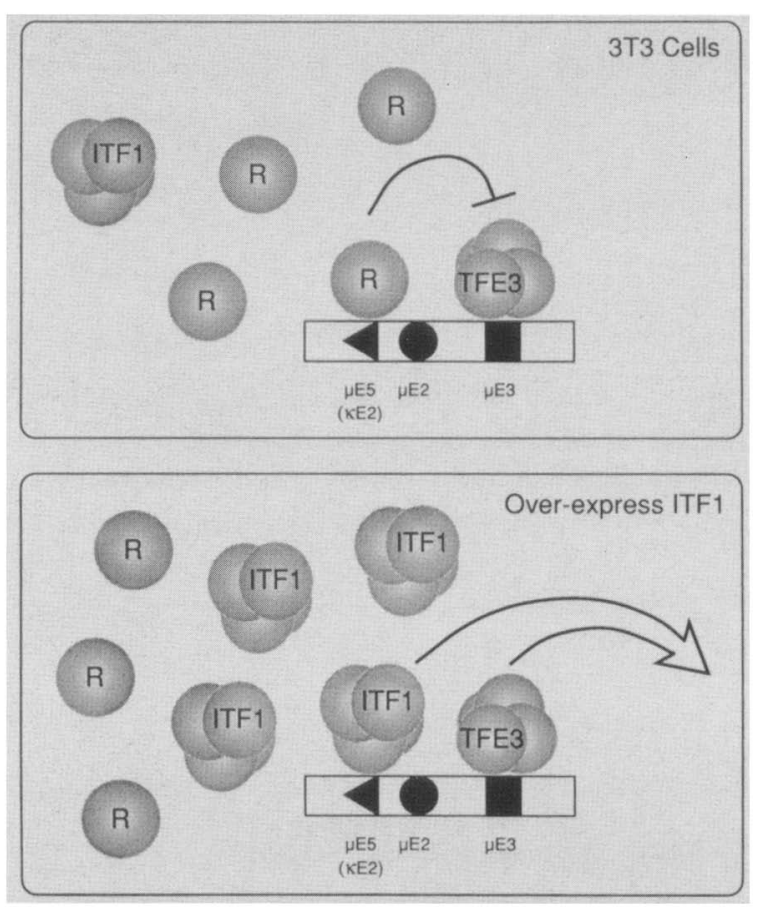

Figure 5. Model for the effect of ITF-1 overexpression on transcriptional activity mediated through the $\mu \mathrm{E} 5$ and $\mu \mathrm{E} 3$ enhancer motifs. (R) Proposed repressor protein or repressor complex. Although a repressed phenotype (normal NIH-3T3 cells, top) shows bound TFE3 protein, we have no evidence for such a bound complex and it is shown here only for the sake of illustration. The bottom panel indicates the proposed situation for NIH-3T3 cells that contain elevated levels of ITF-1 in which both ITF- 1 and TFE 3 are bound and both stimulate transcription (depicted by the large arrow).

constructs and were most apparent with reporters carrying a single copy of the intact enhancer. Although we established the paradigm for negative regulation being a component of the synergy by using multicopy binding sites, we have no compelling reason to suspect that negative regulation is not also occurring with single-copy oligonucleotides or with single-copy enhancers.

\section{Role of a genetic switch in establishing cell type specificity}

Our results indicate that we can reverse cell-type-specific control simply by changing the relative concentrations of a positive-acting transcription factor (ITF-1) and a repressor. Hence, using a broad definition, this system constitutes a genetic switch (Ptashne 1986). Cell type specificity of the IgH enhancer may therefore be a reflection of the relative concentrations of active ITF- 1 and the repressor in B cells and non-B cells. Unfortunately, we cannot yet conclude this for certain since we still know very little about the repressor nor do we understand the nature of the native ITF-1 protein. This latter issue is underscored by two points. First, although the E2A gene (which encodes E12, E47, and ITF-1) is transcribed in both $B$ and non-B cells, there is no evidence that non-B cells produce active ITF-1. Second, ITF-1 
binding itself may be modulated by B-cell-specific proteins (or modifications). This idea stems from the fact that E12 and E47, alternate forms of ITF-1, can interact with a variety of other proteins through their respective helix-loop-helix motifs and that these interactions may influence DNA-binding affinity (Murre et al. 1989a,b|. For example, the heteromers of MyoD and E12 bind to DNA more effectively than either protein alone (Murre et al. 1989b). Although our results suggest that ITF-1 can function on its own (it can also stimulate transcription efficiently in yeast; Henthorn et al. 1990a), our experiments have only measured ITF-1 activity under conditions where the protein is overexpressed. It should be emphasized that our results neither support nor contradict the existence in B cells of a MyoD-like protein that, in conjunction with ITF-1, may bind the $\mu$ E5 more efficiently than ITF-1 alone. Perhaps such a heteromeric ITF-1 complex is the normal species that effectively displaces the repressor, which may itself be ubiquitous. An additional level of complexity to this system is underscored by the recent cloning of cDNAs encoding two additional $\mu$ E3-binding proteins, TFEB and USF (Carr and Sharp 1990; Gregor et al. 1990). It is not yet known whether these proteins can activate transcription through the $\mathrm{IgH}$ enhancer or whether they serve as targets of $\mu \mathrm{E} 5$-mediated repression.

There is ample precedent in eukaryotes for positiveand negative-acting factors binding to adjacent or overlapping sites (for review, see Levine and Manley 1989). In higher eukaryotes, this is best exemplified by the competition among homeo box proteins in Drosophila and by competition among steroid receptor proteins in mammalian cells. In transfection experiments, the Drosophila even-skipped (eve) and engrailed (en) homeo box proteins are potent repressors of the stimulatory activities of both $z 2$ and fushi tarazu homeo box proteins (Jaynes and O'Farrell 1988; Han et al. 1989). Although all of these proteins are able to bind similar DNA sequences, it is not yet clear whether the repressive activity of $e v e$ and $e n$ are merely a consequence of passive competition for activator-binding sites or a consequence of more interactive inhibitory mechanisms. Several examples of steroid hormone-mediated repression suggest direct binding competition between inactive forms of the steroid hormones and positive-acting factors. Competition between an inactive form of the glucocorticoid receptor $(\mathrm{GR})$ and activated CREB protein has been implicated in the control of the human glycoprotein hormone $\alpha$-subunit gene (Akerblom et al. 1988; Oro et al. 1988). Stimulation of a Xenopus vitellogenin gene by estrogen receptor (ER) has been shown to be down-regulated by thyroid hormone receptor (TR) (Glass et al. 1988). In this case the common ER- and TR-binding site represents a negative-acting TR response element (nTRE). In general, nTREs, in the absence of TR, may otherwise bind positive-acting transcription factors (Damm et al. 1989). Although our results play upon these same themes, they are unique in the sense that they involve setting up relatively long-term, lineage-specific transcriptional events in mammalian cells.
Activity of the $\mathrm{IgH}$ enhancer is controlled at multiple levels. The Oct- 2 protein likely contributes to its overall B-cell-specific activity /although the Oct-2 protein is not alone capable of stimulating activity of an enhancer situated $3^{\prime}$ to a transcription unit; Muller et al. 1988). The octamer motif has also been implicated in the enhancer's extinction in $\mathrm{B} \times \mathrm{T}$ hybrid cells (Yu et al. 1989|. A B-cell-restricted activity has also been attributed to a motif adjacent to the $\mu \mathrm{E} 3$ motif, designated $\mu \mathrm{B}$ (Araki et al. 1988; Libermann et al. 1990; Nelsen et al. 1990). Presumably a $\mu$ B-binding protein further activates enhancer activity in B cells. Additional motifs other than $\mu \mathrm{E} 5$ and $\mu \mathrm{E} 3$ are also known to be important for enhancer function. We propose that the genetic switch exemplified by the $\mu \mathrm{E} 5$ and $\mu \mathrm{E} 3$ motifs constitutes only one component of a multilayered mechanism that governs the enhancer's overall B cell specificity.

\section{Materials and methods}

\section{Plasmids}

Plasmids were constructed using standard techniques (Ausubel et al. 1987). The reporter plasmids containing oligonucleotides linked to the liver/bone/kidney alkaline phosphatase (LBK AP) promoter TATA box evolved from pSV2Agpt (Kadesch and Berg 1986) and pL $\Delta 44 \mathrm{cat}(\mathrm{X})$ (Kiledjian and Kadesch 1990). The resulting plasmids (detailed map available on request) contained the following order of sites: BglII, oligo DNA, BamHI, SpeI, $X b a I, B a m H I$, LBK AP TATA box, cat gene. Oligo DNA refers to the various oligonucleotides corresponding to enhancer protein-binding motifs (synthesized by the University of Pennsylvania Cancer Center). The BamHI site that normally exists $3^{\prime}$ to the cat gene in the parental plasmids was destroyed. Sequential duplications of oligonucleotide sequences upstream of the LBK AP promoter were constructed essentially as described by Kiledjian et al. (1988). Reporter plasmids carrying enhancer fragments 2 and 18 have been described elsewhere (Kiledjian et al. 1988). The plasmids pSVE2-5 and pSV2A- $\lambda 3$, which express the ITF- 1 and TFE 3 cDNAs, respectively, from the SV40 early promoter, have also been described elsewhere (Beckmann et al. 1990; Henthorn et al. 1990a). The IgH V1 promoter (Eaton and Calame, 1987) was isolated as a BamHI fragment and used to replace the $\beta$-globin promoter upstream of the cat gene. The $\mu \mathrm{E} 5+\mu \mathrm{E} 2$ and $\mu \mathrm{E} 3$ oligonucleotides are diagramed in Figure 1. The $\kappa E 2$ oligonucleotide was the following (the $\kappa E 2$ motif is underlined):

\section{5'-GATCTCTCCCAGGCAGGTGGCCCAGATTG-3' 3'-AGAGGGTCCGTCCACCGGGTCTAACCTAG-5'}

\section{Cell lines and transfections}

Cell lines were maintained in Dulbecco's modified Eagle medium (DMEM), high glucose, supplemented with $10 \%$ fetal bovine serum, $150 \mu \mathrm{g} / \mathrm{ml}$ glutamine, $100 \mathrm{U} / \mathrm{ml}$ penicillin, and $100 \mu \mathrm{g} / \mathrm{ml}$ streptomycin. The murine plasmacytoma line P3-X63.Ag8 was transfected with $50 \mu \mathrm{g}$ of the various reporter plasmids by calcium phosphate coprecipitation (Kadesch et al. 1986). The plasmid pSV2Apap (20 $\mu \mathrm{g}$ ), which expresses placental alkaline phosphatase (PAP; Henthorn et al. 1988), was included in each experiment to normalize transfection efficiencies. The murine fibroblast line NIH-3T3 was transfected by calcium phosphate coprecipitation /Graham and van der Eb 
1973) using the amounts of reporter and expression plasmids indicated in addition to $5 \mu \mathrm{g}$ of the plasmid $\mathrm{pCH} 110$, which expresses $\beta$-galactosidase (Hall et al. 1983), to normalize transfection efficiencies. Both P3X63.Ag8 and NIH-3T3 cells were harvested $44-48 \mathrm{hr}$ after transfection and assayed first for PAP or $\beta$-galactosidase. Normalized amounts of cell extract were then assayed for CATase (Gorman et al. 1982). Each construct was transfected a minimum of three times.

\section{Evaluation of experimental variation}

We have noted, perhaps due to the use of up to five separate plasmids in our transfections, that CATase values obtained with a common set of plasmids may vary between experiments. However, relative trends obtained from any single transfection series were found to be reproducible. Hence, we have based our experimental conclusions primarily on qualitative changes imparted by ITF-1 and/or TFE3 overexpression rather than on precise quantitative differences.

\section{Acknowledgments}

We thank Li-Kuo Su and Mike Kilediian for helpful comments throughout all phases of this work. This work was supported by funds from the Howard Hughes Medical Institute. H.B. was supported by a grant from the Deutscher Akademischer Austauschdienst DAAD, Sonderprogramm Gentechnologie.

The publication costs of this article were defrayed in part by payment of page charges. This article must therefore be hereby marked "advertisement" in accordance with 18 USC section 1734 solely to indicate this fact.

\section{References}

Akerblom, I.E., E.P. Slater, M. Beato, J.D. Baxter, and P.L. Mellon. 1988. Negative regulation by glucocorticoids through interference with a cAMP responsive enhancer. Science 241: 350-353.

Araki, K., H. Maeda, J. Wang, D. Kitamura, and T. Watanabe. 1988. Purification of a nuclear trans-acting factor involved in the regulated transcription of a human immunoglobulin heavy chain gene. Cell 53: 723-730.

Atchinson, M.L. 1988. Enhancers: Mechanisms of action and cell specificity. Annu. Rev. Cell Biol. 4: 127-153.

Ausubel, F.M., R. Brent, R.E. Kingston, D.D. Moore, J.G. Seidman, J.A. Smith, and K. Struhl. 1987. Current protocols in molecular biology, Greene Publishing Associates/Wiley Interscience, New York.

Beckmann, H., L.-K. Su, and T. Kadesch. 1990. TFE3: A helixloop-helix protein that activates transcription through the immunoglobulin enhancer $\mu \mathrm{E} 3$ motif. Genes Dev. 4: 167179.

Damm, K., C.C. Thompson, and R.M. Evans 1989. Protein encoded by v-erbA functions as a thyroid-hormone receptor antagonist. Nature 339: 593-597.

Carr, C.S. and P.A. Sharp. 1990. A helix-loop-helix protein related to the immunoglobulin $\mathrm{E}$ box-binding proteins. Mol. Cell. Biol. 10: 4384-4388.

Eaton, S. and K. Calame. 1987. Multiple DNA sequence elements are necessary for the function of an immunoglobulin promoter. Proc. Natl. Acad. Sci. 84: 7634-7638.

Gillies, S.D., S.L. Morrison, V.T. Oi, and S. Tonegawa. 1983. A tissue specific transcription enhancer element is located in the major intron of the immunoglobulin heavy-chain gene. Cell 33: 717-728.

Glass, C.K., J.M. Holloway, O.V. Derary, and M.G. Rosenfeld.
1988. The thyroid hormone receptor binds with opposite transcriptional effects to a common sequence motif in thyroid hormone and estrogen response elements. Cell 54: 313-323.

Gorman, C.M., L.F. Moffat, and B.H. Howard. 1982. Recombinant genomes which express chloramphenicol acetyltransferase in mammalian cells. Mol. Cell. Biol. 2: 1044-1051.

Graham, F.L. and A.J. van der Eb. 1973. A new technique for the assay of infectivity of human adenovirus 5 DNA. Virology 52: $456-467$.

Gregor, P.D., M. Sawadogo, and R.G. Roeder. 1990. The adenovirus major late transcription factor USF is a member of the helix-loop-helix group of regulatory proteins and binds to DNA as a dimer. Genes Dev. 4: 1730-1740.

Hall, C.V., P.E. Jacob, G.M. Ringold, and F. Lee. 1983. Expression and regulation of Escherichia coli lac $\mathrm{Z}$ fusions in mammalian cells. I. Mol. Appl. Genet. 2: 101-110.

Han, K., M.S. Levine, and J.L. Manley. 1989. Synergistic activation and repression of transcription by Drosophila homeobox proteins. Cell 56: 573-583.

Henthorn, P., P. Zervos, M. Raducha, H. Harris, and T. Kadesch. 1988. Expression of a human placental alkaline phosphatase gene in transfected cells: Use as a reporter for studies of gene expression. Proc. Natl. Acad. Sci. 85: 63426346.

Henthorn, P., M. Kilediian, and T. Kadesch. 1990a. Two distinct transcription factors that bind the immunoglobulin enhancer $\mu E 5 / \kappa E 2$ motif. Science 247: 467-470.

Henthorn, P., R. McCarrick-Walmsley, and T. Kadesch. 1990b. Sequence of the cDNA encoding ITF-1, a positive-acting transcription factor. Nucleic Acids Res. 18: 677.

Imler, J.-L., C. Lemaire, C. Wasylyk, and B. Wasylyk. 1987. Negative regulation contributes to tissue specificity of the immunoglobulin heavy-chain enhancer. Mol. Cell. Biol. 7: $2558-2567$.

Jaynes, E.E. and P.H. O'Farrell. 1988. Activation and repression of transcription by homoeodomain-containing proteins that bind a common site. Nature 336: 744-749.

Kadesch, T.R. and P. Berg. 1986. Effects of the position of the simian virus 40 enhancer on expression of multiple transcription units in a single plasmid. Mol. Cell. Biol. 6: 25932601.

Kadesch, T., P. Zervos, and D. Ruezinsky. 1986. Functional analysis of the murine $\mathrm{IgH}$ enhancer: Evidence for negative control of cell-type specificity. Nucleic Acids Res. 14: 8209-8221.

Kamps, M.P., C. Murre, X. Sun, and D. Baltimore. 1990. A new homeobox gene contributes the DNA binding domain of the $\mathrm{t}(1 ; 19)$ translocation protein in pre-B ALL. Cell 60: 547-555.

Kiledjian, M. and T. Kadesch. 1990. Analysis of the human liver/bone/kidney alkaline phosphatase promoter in vivo and in vitro. Nucleic Acids Res. 18: 957-961

Kiledjian, M., L.-K. Su, and T. Kadesch. 1988. Identification and characterization of two functional domains within the murine heavy-chain enhancer. Mol. Cell. Biol. 8: 145-152.

Ko, H.-S., P. Fast, W. McBride, and L.M. Staudt. 1988. A human protein specific for the immunoglobulin octamer DNA motif contains a functional homeobox domain. Cell 55: $135-144$.

Lenardo, M., J.W. Pierce, and D. Baltimore. 1987. Proteinbinding sites in Ig gene enhancers determine transcriptional activity and inducibility. Science 236: 1573-1577.

Levine, M. and J.L. Manley. 1989. Transcription repression of eukaryotic promoters. Cell 59: 405-408.

Libermann, T.A., M. Lenardo, and D. Baltimore. 1990. Involvement of a second lymphoid-specific enhancer element in the 
regulation of immunoglobulin heavy chain gene expression. Mol. Cell. Biol. 10: 3155-3162.

Muller, M.M., S. Ruppert, W. Schaffner, and P. Matthias 1988. A cloned octamer transcription factor stimulates transcription from lymphoid-specific promoters in non-B cells. $\mathrm{Na}$ ture 336: 544-551.

Murre, C., P. Schonleber-McCaw, and D. Baltimore 1989a. A new DNA binding and dimerization motif in immunoglobulin enhancer binding, daughterless, MyoD, and myc proteins. Cell 56: 777-783.

Murre, C., P. Schonleber-McCaw, H. Vaessin, M. Caudy, L.Y. Jan, Y.N. Jan, C.V. Cabrera, J.N. Buskin, S.D. Hauschka, A.B. Lassar, H. Weintraub, and D. Baltimore. 1989b. Interactions between heterologous helix-loop-helix proteins generate complexes that bind specifically to a common DNA sequence. Cell 58: 537-544.

Nelsen, B., T. Kadesch, and R. Sen. 1990. Complex regulation of the immunoglobulin $\mu$ heavy chain gene enhancer: $\mu B$, $a$ new determinant of enhancer function. Mol. Cell. Biol. 10: $3145-3154$.

Nourse, J., J.D. Mellentin, N. Galili, J. Wilkinson, E. Stanbridge, S.D. Smith, and M.L. Cleary 1990. Chromosomal translocation $t(1 ; 19)$ results in synthesis of a homeobox fusion mRNA that codes for a potential chimeric transcription factor. Cell 60: 535-545.

Oro, A.E., S.M. Hollenberg, and R.M. Evans 1988. Transcriptional inhibition by a glucocorticoid receptor- $\beta$-galactosidase fusion protein. Cell 55: 1109-1114.

Peterson, C.L. and K. Calame. 1989. Proteins binding to site C2 $(\mu \mathrm{E} 3)$ in the immunoglobulin heavy-chain enhancer exist in multiple oligomeric forms. Mol. Cell. Biol. 9: 776-786.

Perez-Mutul, J., M. Macchi, and B. Wasylyk. 1988. Mutational analysis of the contribution of sequence motifs within the $\mathrm{IgH}$ enhancer to tissue specific transcriptional activation. Nucleic Acids Res. 16: 6085-6096.

Ptashne, M. 1986. A genetic switch. Cell Press and Blackwell Scientific Publications, Palo Alto

Roman, C., J.S. Platero, J. Shuman, and K. Calame. 1990. Ig/ EBP-1: A ubiquitously expressed immunoglobulin enhancer binding protein that is similar to C/EBP and heterodimerizes with C/EBP. Genes Dev. 4: 1404-1415.

Scheidereit, C., J.A. Cromlish, T. Gerster, K. Kawakami, C.G. Balmaceda, R.A. Currie, and R.G. Roeder. 1988. A human lymphoid-specific transcription factor that activates immunoglobulin genes is a homoeobox protein. Nature 336: $551-$ 557.

Tsao, B.P., X.-F. Wang, C.L. Peterson, and K. Calame 1988. In vivo functional analysis of in vitro protein binding sites in the immunoglobulin heavy chain enhancer. Nucleic Acids Res. 16: 3239-3253.

Wasylyk, C. and B. Wasylyk. 1986. The immunoglobulin heavy-chain B lymphocyte enhancer efficiently stimulates transcription in nonlymphoid cells. EMBO J. 5: 553-560.

Weinberger, J., P.S. Jan, and P.A. Sharp. 1988. Localization of a repressive sequence contributing to $B$-cell specificity in the immunoglobulin heavy-chain enhancer. Mol. Cell. Biol. 8: $988-992$.

Yu, H., B. Porton, L. Shen, and L. Eckhardt. 1989. Role of the octamer motif in hybrid cell extinction of immunoglobulin gene expression: Extinction is dominant in a two enhancer system. Cell 58: $441-448$. 


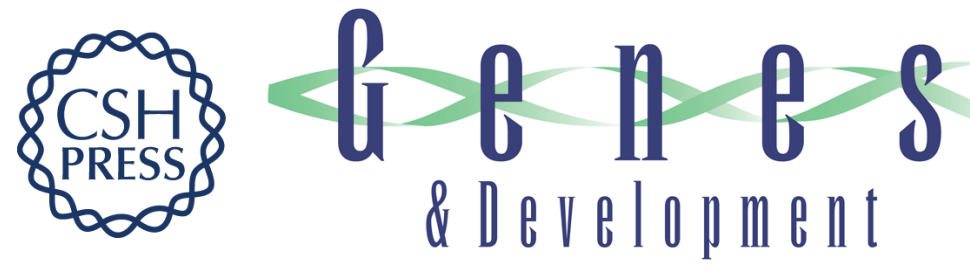

\section{Modulation of the IgH enhancer's cell type specificity through a genetic switch.}

D Ruezinsky, H Beckmann and T Kadesch

Genes Dev. 1991, 5:

Access the most recent version at doi:10.1101/gad.5.1.29

References This article cites 42 articles, 16 of which can be accessed free at:

http://genesdev.cshlp.org/content/5/1/29.full.html\#ref-list-1

License

Email Alerting

Service

Receive free email alerts when new articles cite this article - sign up in the box at the top right corner of the article or click here.

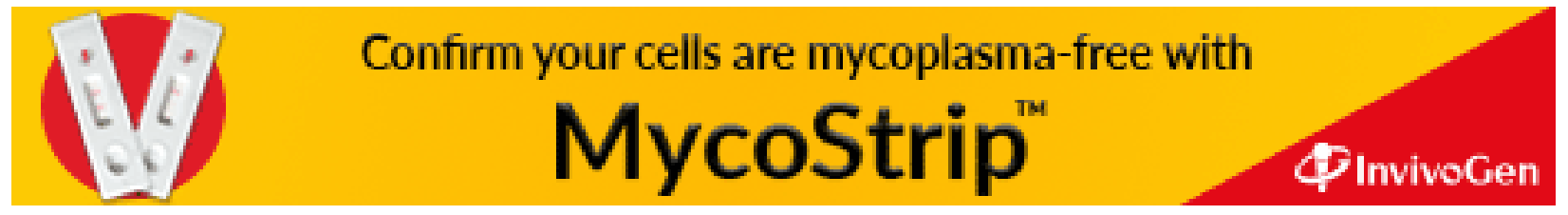

